"Should the United States simply relegate Afghanistan, and South Asia in general, to the outer fringes of its concerns once bin Laden and his acolytes in the Al Q aeda terror network have been either prosecuted or destroyed, Afghanistan could again become a fertile arena for the genesis of other militant Islamist organizations intent on wreaking havoc on the Western world."

\title{
Putting South Asia Back Together Again
}

\author{
SUMIT GANGULY
}

$\longrightarrow$ hortly after the September 11 terrorist attacks, the first war of the twenty-first century erupted as the United States began the aerial bombardment of Taliban-controlled Afghanistan. The locus of this new war surprised many: most discussion and predictions of United States military action over the past decade envisioned a war in East Asia- with China over Taiwan, or with North Korea- or in the Middle East. Instead, the countries of South Asia are now the focus of the world's attention.

The military action that has been undertaken to unearth the roots of terrorism in South Asia comes fraught with geopolitical dangers. Pakistan has placed itself in an extremely tenuous position-as a Muslim country supporting a war against another Muslim country, as a military dictatorship without domestic or international legitimacy, and as home to a plethora of Islamist groups that have been implicated in terrorist acts in South Asia and beyond. India, which has long been complaining to the international community about the terrorist strikes it has endured for the past dozen years, is being asked to exercise restraint in the face of continuing provocations. Muslim states spanning half the globe, from Indonesia to Saudi Arabia, face rising tides of internal dissent. Some of this dissent is closely linked to longtime American support for quasi-authoritarian regimes in the Middle East. The path that the United States has laid out for itself- to vanquish terrorism and the regimes that support or enable it - is armed with its own risks.

Should the United States simply relegate Afghanistan, and South Asia in general, to the outer fringes of its concerns once Osama bin Laden and his

SUMIT GANGULY is a professor of Asian studies and government at the $U$ niversity of Texas at Austin and is the author of the forthcoming Conflict Unending: Indo-Pakistani Tensions since 1947 (New York: Columbia U niversity Press). acolytes in the Al Qaeda terror network have been either prosecuted or destroyed, Afghanistan could again become a fertile arena for the genesis of other militant Islamist organizations intent on wreaking havoc on the Western world. Such willful amnesia about Afghanistan and the concomitant demise of policy attention would ill serve American interests. What should the United States do to lessen the chances that its current actions will simply lay another minefield to be negotiated 10 years further down the road? Part of the answer to that question can be found in looking back at the reasons why Afghanistan, and the region as a whole, became a haven for malign forces.

\section{AFghANISTAN'S RUPTURED HISTORY}

Afghan society suffered considerably in the last few decades of the twentieth century. Its recent spate of conflict and despair started in 1973 with the overthrow of King M ohammed Zahir Shah by his ambitious cousin, Mohammed Daoud. A series of coups and countercoups followed until the Soviet Union invaded Afghanistan in December 1979 in an attempt to prevent what had become a socialistoriented regime on its borders from collapsing. It was also an attempt to prevent the percolation of a brand of radical Islam into the Soviet Central Asian republics, where Islamist disaffection with Moscow was al ready brewing.

The regime of Babrak Karmal that the Soviet army installed quickly became the focus of widespread international opposition. The Soviet invasion was overwhelmingly condemned in the United Nations. The United States, under the leadership of its newly inaugurated president, Ronald Reagan, whose initial years in power were marked by demonization of the Soviet Union, embarked on a campaign to curb Soviet expansionism on a global 
basis and made Afghanistan one of its principal battlegrounds in that campaign. To this end, it elicited the support of the Pakistani military dictatorship of President M ohammed Zia-ul-Haq in supplying and training the mujahideen, the various groups fighting the Soviet invaders.

Reagan's predecessor, Jimmy Carter, had ostracized Zia's regime because of its abysmal human rights record and its feckless pursuit of nuclear weapons. After the Soviet invasion of Afghanistan the United States government overlooked the Zia regime's significant democratic deficit and its headlong pursuit of nuclear weapons. It also acquiesced to the extortionate demands of the Pakistani army's counterintelligence organization, the Inter-Services Intelligence agency ( ISI). This shadowy organization, unaccountable to any entity but the highest echelons of the Pakistani military and the dictator himself, obtained control over the aid pipeline to the Afghan mujahideen.

General Zia, meanwhile, was intent on bolstering his own domestic legitimacy by courting the Muslim clergy within Pakistan. As a result, and with the tacit acceptance of the Central Intelligence Agency, Zia's minions in the ISI directed a disproportionate amount of the American assistance to the most religiously zealous mujahideen organization in Afghanistan-the Hizb-i-Islami-even though this group was not at the forefront of the military confrontations with the Soviet army. Armed with Pakistani-supplied American weaponry and Saudi money, Gulbuddin Hekmatyar, the leader of the Hizb-i-Islami, and his followers were given free rein in the Afghan refugee camps that had been formed in western Pakistan. There Hekmatyar's forces began to indoctrinate many young, hapless Afghan men, both to fight against the infidels who had come to occupy their country and to adhere to a particularly harsh and unyiel ding form of Islam.

The American-aided war against the Soviet occupation was slow but eventually successful. After 10 years of fighting, the Soviet government, now led by Mikhail Gorbachev, finally decided to withdraw from Afghanistan. As Soviet troops left, they replaced Karmal with Mohammed Najibullah, a Pashtun (one of the country's largest ethnic groups), who had been the head of KHAD, Afghanistan's dreaded intelligence and espionage organization. Within months, the various mujahideen groups were challenging the $\mathrm{Najibullah}$ regime and fighting among themselves in a wasteful civil war. Thanks to the significant military and organizational resources at Najibullah's command, he managed to cling to power until 1992.
In the end, Najibullah was ousted not by the Isı's favorite, Gulbuddin Hekmatyar, who had demonstrated far greater skill in proselytization than in battle tactics, but by the forces of the ethnically Tajik leader Ahmed Shah Massoud. After Najibullah's fall, Pakistan attempted to broker a powersharing arrangement among the various insurgent groups, who were still divided along lines of ideology, tribal loyalty, and personality. Massoud and his political mentor, Burhanuddin Rabbani, however, proved incapable of reaching any viable accommodation with the other mujahideen organizations.

\section{ENTER THE TALBAN}

As civil war and unrest continued to shred the remnants of Afghan society, another, far more vicious group was forming in the refugee camps in Pakistan. This new force was composed of young men who had grown up in the camps during the Soviet occupation of Afghanistan, detached from the normal ties of kith and kin and imbued with radical Islamic fervor in the madrassas (Islamic schools) that Saudi financiers had set up in the refugee camps. Left to themselves, these young men might have joined one of the many mujahideen groups fighting the Soviet Union in Afghanistan, or they might have become members of one of the various insurgent groups that the ISI was also nurturing to spread terror in the Indian-controlled portion of the disputed state of Jammu and Kashmir, where an indigenously based insurgency had erupted in 1989.

But these taliban (students) from the madrassas were singled out by the Harvard-educated prime minister of Pakistan, Benazir Bhutto (who had been elected after Zia died in 1988 in a plane crash), and her interior minister, N aserullah Babar, a former military officer, and were carefully organized into a viable fighting force. Bhutto hoped to use this group of religious zealots as a pliant entity to serve Pakistan's strategic interests in Afghanistan. Bhutto and Babar, along with significant segments of the Pakistani strategic community, believed these fighters could bring to power a regime dependent on and grateful to Pakistan, thereby giving Pakistan "strategic depth" in the event of yet another conflict with its long-standing adversary, India.

Even after the fall of Bhutto's government, successive Pakistani regimes continued the policies she had initiated, and in 1996 the Taliban successfully overthrew the Rabbani regime. Afghanistan's battleweary population initially greeted the Taliban as liberators who could bring some stability to their 
beleaguered land. As with most things in Afghanistan, their joy did not last long.

Almost immediately, the Taliban ruthlessly eliminated nearly all sources of opposition. Massoud's forces, reeling from the organization, zeal, and Pakistani-supplied firepower of the Taliban, were forced to take refuge in the Panjshir Valley in northern Afghanistan. Within the territories of Afghanistan that they came to control, the Taliban promptly moved to impose their strictures on the population. Their views and practices were utterly obscurantist. Their misogyny seemed to know no bounds, and they evinced an extraordinary intolerance toward other religious groups and other Islamic sects. Violators of their decrees were met with draconian punishment.

\section{AMERICA'S ROLE}

The Taliban had found support not only from their original sponsors, the Saudis and the Pakistanis, but also from the United States. The United States tacitly supported the Taliban because they appeared to have brought a degree of stability to Afghanistan. The American policy was also encouraged by the lobbying of some powerful American oil companies that were actively seeking to build a gas pipeline across Afghanistan from the Central Asian states to Pakistan. Only when steady reports of the Taliban's retrograde practices toward women caught the attention of American feminist and human rights groups did the United States start to waver in its support for the Taliban.

Soon the United States would have other reasons to be ill disposed toward the Taliban. In 1996 Osama bin Laden, the son of a Saudi construction magnate, moved to Afghanistan after he had been ousted from Saudi Arabia and then Sudan for his terrorist activities. The Taliban welcomed him to Afghanistan because he shared their deep distrust of the United States, adhered to the same austere version of Islam they practiced, and benefited them with his financial largesse.

Bin Laden's hatred for the United States stemmed from a variety of sources. Like many radical Arabs, he was unalterably opposed to American support for Israel. He also believed that the presence of United States troops had defiled the soil of Islam's sacred land, Saudi Arabia, and he was opposed to American support for what he believed was a corrupt Saudi monarchy. Two years after his arrival in Afghanistan, bin Laden and his radical Islamic organization, Al Q aeda, were implicated in the bombings of American embassies in Kenya and Tanzania.

\section{THE INDIAN CONNECTION}

As the Taliban consolidated its hold over Afghanistan, they played host not only to bin Laden and Al Q aeda but also to a variety of other ISI-supported groups that were intent on carrying their jihad into the Indian-controlled portions of Jammu and Kashmir. These groups, comprising Afghans, Arabs, Pakistanis, and disaffected Kashmiris, contributed to a reign of terror and mayhem throughout the Kashmir Valley during the last decade of the twentieth century. The Indian security forces resorted to harsh counterinsurgency tactics in attempts to defeat them. Often the native Kashmiri population found itself caught in the crossfire between the brutal tactics of the insurgents and the repressive methods of the Indian forces.

Despite the continuing alienation of Kashmir's population from the Indian state, toward the end of the 1990s the insurgency started to wane. The local population, while unhappy with India, had developed a deep distaste for the Islamic zeal ots who had turned the initial uprising into a ruthless protection racket with religious overtones.

M eanwhile, Indian national leaders repeatedly asked the United States to take notice of Pakistan's deep involvement with the various insurgent organizations, all of which were headquartered in Pakistan. They also tried to persuade the international community to recognize these organizations' fundamental character as purveyors of terror. Despite the viciousness of their attacks on civilian populations in Kashmir and elsewhere in India, the insurgents have until now escaped the disapprobation of the international community and have not been labeled as terrorist organizations by the U nited States.

Against this backdrop, a set of related events rocked the subcontinent. In May 1998, India carried out five nuclear tests. Not surprisingly, and despite American blandishments and offers of economic assistance, Pakistan carried out its own set of tests within two weeks. The tests refocused international attention on the Kashmir dispute; key nations, particularly the United States, sounded the dual tocsins of nuclear proliferation and the danger of renewed conflict between India and Pakistan. The volatility of the Kashmir dispute, which had precipitated two earlier wars between India and Pakistan (in 1947-1948 and 1965), now raised worldwide concern about the prospect of nuclear war in the region. In an effort to assuage these concerns, Prime Minister Atal Behari Vajpayee of India met with Prime M inister Nawaz Sharif of Pakistan in February 1999. Their meeting led to a set of 
agreements designed to reduce Indo-Pakistani tensions, especially in the nuclear realm.

The gains of the Lahore summit evaporated in the thin air of the Himalayas when in late April 1999, units of the Pakistani N orthern Light Infantry, along with Pakistani and Afghan irregulars, scaled heights of over 14,000 feet to breach the Line of Control ( $\mathrm{LOC})$, the de facto international border in Kashmir. The Indian forces, who had been lulled into a state of complacency in the aftermath of the February 1999 summit, were unprepared for the well-organized, Pakistan-sponsored infiltration, which took place in the heights above Kargil and at two other points along the LoC. After overcoming the initial shock, the Indian troops retaliated with considerable vigor. Nevertheless, it took them nearly two and a half months to dislodge all the intruders from the mountain redoubts.

Although the Indians resorted to the use of airpower before launching the final infantry assaults on the well-entrenched

Pakistani positions, they

did not move to hori-

zontal escalation as they

had done in previous

conflict-especially in

1965- to relieve pres-

sure in the Kashmir sector. Nor did the Indian forces cross the LoC in attempts to destroy Pakistani and insurgent bases. The Indian unwillingness to expand the scope and the intensity of the conflict can be attributed to a clear-cut recognition that Pakistan was now a nuclear-weapons state. Indian decision makers could not afford to provoke Pakistani anxieties in a fashion that could lead to nuclear escalation.

Even though India did not lose any territory in the Kargil war, the sense of injured innocence that pervaded New Delhi undermined any prospect of Indo-Pakistani rapprochement. Worse still, Pakistani Prime M inister Nawaz Sharif was overthrown in a military coup in October 1999, in part because of the fallout of the Kargil defeat. Although General Pervez Musharraf, the military dictator who took power after the coup, publicly called for renewed talks with India, he actually created more permissive conditions for the mujahideen to carry out their war against India in Kashmir. As the insurgency in Kashmir proceeded apace, Indo-Pakistani relations declined precipitously.

\section{IN TERSECTING IN TERESTS}

Indo-Pakistani relations will remain strained as long as the Kashmir conflict persists. That conflict, in turn, will continue as long as Pakistan maintains its support of the various guerrillas fighting in Kashmir and India remains unable to grant the Kashmiris in its jurisdiction a fair political dispensation. Yet, the American "war on terrorism," if properly fashioned, could provide the means for bringing an end to this conflict.

Of course, the United States cannot confine its strategic goals to simply defeating bin Laden and his associates, for that would leave untouched the milieu in which the various terrorist and insurgent groups formed and developed. Unless the social, political, and economic conditions that spawned Al Q aeda and other associated groups are addressed, the United States and its allies in Western Europe and elsewhere will continue to be targeted by Islamist terrorists. To forestall such outcomes the United States, in concert with the relevant United Nations agencies, will have to restore some semblance of state authority to Afghanistan. The United States has provided varying degrees of support to the reconstruction of war-torn societies in both Cambodia and East Timor; these examples should be the models for a program of state building in Afghanistan, where more vital and immediate United States interests are implicated.

Forging such a strategy will first entail a longterm and expansive American commitment to the region. This will require devoting both material and human resources to the reconstruction of Afghanistan. It will also involve helping the United Nations and other regional actors, especially Pakistan and India, promote a broad-based post-Taliban regime in Afghanistan. Such a regime would have to comprise members of all of the country's major ethnic groups-Pashtuns, Tajiks, Uzbeks, and Hazaras. To prevent a return to the warlordism that consumed Afghanistan after the fall of $\mathrm{N}$ ajibullah, and to monitor a program of disarming on the part of ethnic and private militias, a un peacekeeping force will have to remain in the country for a number of years. The most difficult part of the process may be to find a political leader behind which all Afghans can coalesce and who will also be accepted by Pakistan, India, and Russia. As this time, the only possible such leader appears to be the aged exiled king, Zahir Shah, already in his late 80s.

Because the participation of Pakistan and India will be crucial to this effort, the United States must 
play an active role in ameliorating Indo-Pakistani relations. To enlist Pakistan's wavering support for the prosecution of its war aims against bin Laden and his hosts in Afghanistan, the United States has lifted a panoply of sanctions that it had imposed on Pakistan in the aftermath of the nuclear tests and the military coup in 1999. It has also offered to help alleviate Pakistan's dire economic plight through the deferral of various loan payments and the provision of new resources from the International Monetary Fund. Discussions are now under way to also provide modest military assistance to Pakistan's armed forces.

As a consequence, the United States now has considerable leverage over the Pakistani politicomilitary elite. Washington must not squander this opportunity to push for a reorientation of Pakistan's domestic and external priorities as well as a reshaping of some of Pakistan's internal institutional arrangements. It is especially important that the United States urge the military regime of General Pervez Musharraf to spell out a viable strategy for returning Pakistan to civilian rule. To facilitate this transfer of power, the United States should direct some of its assistance to the strengthening of civil society and civic institutions in Pakistan. Such actions and strategies are hardly without precedent in United States-Pakistan relations.

More specifically, the United States must unequivocally press Pakistan to terminate its support of the various insurgent groups operating from Pakistani territory. The vast majority of these groups have directed their wrath against India. Their ideological inclinations and political proclivities are such that they pose a danger well beyond their current activities in Kashmir, however. When the Kashmir insurgency eventually ends, whether through military suppression or negotiation, these groups will begin to look for other targets, as long as they still have succor, support, and sanctuaries. Once their anti-Indian spleen has been vented there is little reason to believe that they would not direct their attention to Israel, the United States, or the Western world in general. Consequently, although the Pakistani military may be loath to admit it, these groups do pose a long-term threat to the internal stability and governance of Pakistan.

More than a decade of support to these insurgent groups, not to mention three wars with India over Kashmir, have not brought Pakistan any closer to its goal of tearing Kashmir away from the Indian union. The time has arrived to dispense with this futile quest and accept the inevitable: the status quo in Kashmir should be permanently frozen and the hopes of merging all Kashmir into Pakistan abandoned.

To be politically viable, this strategy must have another critical component. No Pakistani leadership will be able to end the activities of these groups unless it can exact some concessions from India on the Kashmir front. Again, the United States can and should play an important role here. Washington has recently started to dramatically improve its relations with New Delhi. The acrimony and distrust that long characterized Indo-American relations now seems to be at least on hold, if not entirely at an end. Careful American diplomacy can induce India to undertake certain vital steps to restore normal cy in its portion of Kashmir. Specifically, the United States should prod India to reestablish Kashmir's autonomy-guaranteed by the Indian constitution but often compromised by the Indian government. To win the "hearts and minds" of ordinary Kashmiris, India should also steadily reduce its military and paramilitary presence within Kashmir as Pakistanisponsored support for the terrorists draws to a close. It must also honestly address widespread allegations of human rights abuses on the part of its security forces. Finally, as some semblance of political order is restored in Kashmir, India will need to a make a concerted attempt to promote economic development in the state to create new employment opportunities. Such efforts will assuage many grievances of a generation that has known little except violence and upheaval. None of these tasks will be easy or swift. However, the alternative to the pursuit of these ameliorative measures means the continuation of a degrading, sanguinary, and risk-laden strategy in Kashmir and the continuing prospect of wider political upheavals in the region and beyond. 